NAMA : MARSANDA

NIM : 50400121003

KELAS : MD_A1

"Resume Filsafat Dakwah Syekh Yusuf Al-Makassary" .

Dr. Mustari Mustafa

\title{
AGAMA DAN \\ BAYANG-BAYANG ETIS \\ Syaikh Yusuf \\ Al-Makassari
}

LKís

PENGANTAR REDAKSI

Buku ini menyajikan tokoh Syaikh al-Haj Yusuf Abu al Mahasin Hadiyatullah al-Taj al-Khalwati alMaqashshariy atau lebih dikenal sebagai Syaikh Yusuf Al-Makassari. Gelar syaikh yang disandang putra Makassar ini memiliki makna universal, yangdalam sejarah Nusantara berhubungan dengan ulama yang menguasai dunia tasawuf. la adalah tokoh historis yang mengembangkan ajaran etika religius dalam dakwahnya.Ajarannya bersumber dari kitab suci, tradisi, dan pemikiran tokoh tokoh sejarah. la berhasil membawa Islam sebagai agama yang berkembang di dalam masyarakat yang majemuk, yang kaya akan pandangan-pandangan atau 
nilai-nilai tradisional

Pijakan utama etika religius Syaikh Yusuf bersumber darikonsepsi Al-Qur'an tentang manusia dan kedudukannya di dalam alam semesta. Konsep teologi yang digunakan bercorak sufisme. Menurutnya, "hakikat manusia sebagai bayangan Tuhan di mukabumi" disebut sebagai konsep Al-Insan Al-Kamil. Konsep ini berfokus pada spiritualitas yang dapat mengantar manusia ke alam Ilahiah (alam ketuhanan), melalui potensi batin yang dimilikinya.Selama hidupnya, Syaikh Yusuf telah menghasilkan puluhankarya/naskah, yang fokus utamanya adalah tasawuf dan etikadakwah. Di dalam karya-karyanya juga, Syaikh Yusuf mengulas tentang kaifiyat dzikir, yaitu dzikir yang mencakup etika religius lahir dan batin, sebagai pancaran kesempurnaan tauhid, makrifat, dan ibadah. la juga menjelaskan tentang makna kalimat tauhid La ilaaha illa Allah. Dalam kitab Mathalib Salikin misalnya, Syaikh Yusuf menekankan pentingnya memahami tauhid sehingga tidak mudah terjatuh pada kemusyrikan. Syaikh Yusuf dikenal sebagai ulama pengembara untuk berguru kepada syaikh/ulama yang dikenal mumpuni. Setelahbelajar agama di Makassar, kehausannya terhadap ilmu-ilmuagama dilanjutkan dengan mengembara ke daerah-daerah di Tanah Air terutama ke Banten dan Aceh, serta negara-negara Arab. Syaikh Yusuf meninggal di Cape Town Afrika Selatan setelah diasingkan oleh penjajah kolonial Belanda akibat dakwah dan perjuangannya bersama Sultan Banten. Selama empat tahun di Cape Town, Syaikh Yusuf berhasil membangun komunitas muslimyang solid, sehingga oleh pemerintah Afrika Selatan dinugerahi gelar pahlawan nasional. Demikianlah poin-poin penting yang disuguhkan dalam kajian tentang Syaikh Yusuf ini. Dalam konteks dakwah Islam Indonesia, kajian tentang etika religius Syaikh Yusuf perlu dikembangkan, karena pesan dakwahnya mencerminkan nilai-nilai Islam yang toleran, damai, dan jauh dari tindakan-tindakan anarkis dan teror terhadap kelompok-kelompok masyarakat yang lain. Oleh karena itu, selayaknyalah pesanpesan Islam yang damai ini menjadi bagian dari hidup kita dalam beragama, bermasyarakat, dan bernegara. Kami sampaikan terima kasih kepada Bapak Mustari Mustafa yang telah mempercayakan karyanya ini untuk kami terbitkan. Dan, kepada sidang pembaca yang budiman, buku ini layak dikedepankan untuk mengisi kekeringan religiusitas kita dalam satu dekade terakhir ini. Selamat membaca!

\section{PENGANTAR PENULIS}

\section{Dr. Mustari Mustafa}

Keterlibatan saya sebagai pengajar dan mubalig merupakan stimulus tersendiri dalam melakukan penelitian ini. Tokoh Syaikh

Yusuf menjadi objek kajian karena beliau dikenal sebagai ulama, mubalig, sufi, ahli tarekat, dan pejuang yang menguasai dan meng amalkan ajaran Islam, baik 
lahir maupun batin. Metode dakwahnya yang adaptif sesuai dengan karakter masyarakat Indonesia yang plural serta kaya akan nilai-nilai tradisional. Etika religius Syaikh Yusu bersumber dari Al-Qur'an, sunnah, dan filsafat, serta bercorak sufisme. Unsur utama pemikiran Syaikh Yusuf berpusat pada Tuhan, dunia, dan manusia. Menurutnya, manusia adalah bayangan Tuhan di muka bumi yang disebut sebagai Al-Insan al Kamil. Dalam karyanya, Zubdatul Asrar, Syaikh Yusuf menekan kan pentingnya etika terhadap Tuhan dan alam semesta. Dari segi pengembangan dakwah, metode Syaikh Yusuf yang adaptif dapat dikatakan berbeda dengan model dakwah yang dilakukan oleh ulama lainnya, sehingga corak dakwahnya perlu dikembangkan dan diapresiasi. Model dakwah Syaikh Yusuf bercorak mengayomi dan mencerahkan, serta jauh dari pemaksa an dan anarkisme terhadap kelompok-kelompok lain. Sebagai sufi yang memiliki keluasaan ilmu dan berkepribadiankuat, Syaikh Yusuf tak kenal lelah berjuang dalam menegakkan Islam dan melawan penjajahan, termasuk ketika diasingkan ke Cape Town Afrika Selatan. Tak heran, Presiden Nelson Mandella (ketika itu) pernah menyatakan bahwa Syaikh Yusuf merupakan salah satu insipiratornya dalam memperjuangkan kemerdekaan dan persamaan hak di Afrika.

Di lingkungan Universitas Islam Negeri Alaudin Makassar, saya mengucapkan terima kasih kepada rektor, dekan, dan jajaran pimpinan Fakultas Dakwah dan Komunikasi Universitas Islam Negeri Alauddin Makassar, yang telah memberikan kesempatan belajar kepada saya. Tak lupa juga kepada Prof. Dr. M. Sattu Alang, M.A., yang pernah menjadi Dekan Fakultas Dakwah dan Komuni kasi Universitas Islam Negeri Alauddin, yang telah memberikan dorongan, semangat, dan menantang saya untuk melanjutkan studi.

Prof. Dr. Andi Rasdiyanah Amir dan Drs. Amir Said (alm.)merupakan sosok yang memiliki tempat tersendiri bagi saya karena mereka menjadikan penelitian ini kaya dengan analisis antropologis melalui penelitian yang telah dilakukannya. Tak lupa juga kepada Prof. Dr. M. Saleh A. Putuhena (alm.), Prof. Dr. Moch. Qasim Mathar, M.A., Prof. Dr. A. Qadir Gassing H.T.,M.S., Prof. Dr. Ahmad M. Sewang, M.A., Dr. Sampo Seha, M.Sos.I., dan Mendiang Drs. Husain Sulaiman, M.Ag.

Saya juga ingin mengucapkan terima kasih kepada Bapak Sayun, M.Si. sekeluarga yang telah membagi ilmu serta peng alamannya; sebagai om, beliau sudah memberi warna tersendiri, kadang-kadang saya merasa proses studi serasa berjalan dengan kedekatan keluarga besar. Demikian juga keberadaan om, kakak, adik serta anak-anak lainnya di Yogyakarta yang telah membantu sehingga penulisan ini sampai pada tahap sekarang ini. Saya harus menghaturkan penghargaan dan ucapan terima kasih kepada Bapak H. Mustafa Ibrahim serta Ibu Hj. Semia, orangtua saya yang sangat saya hormati dan cintai. Mereka tela merawat, mendidik, mendewasakan, mengajarkan huruf alif sampai yaa' hingga saya dapat menempuh jenjang pendidikan tertinggi.

Ketika hendak mengakhiri ucapan terima kasih ini, saya ter ingat mendiang Ibu Hanung yang merupakan sosok penuh cinta dan kasih, yang telah merawat dan mendidik saya hingga seperti 
sekarang ini. Kakak dan adik-adik tercinta, mendiang Musta'ami sek, Drs. H. Sahidin Mustafa S.H., M.H., sek, Siti Ratna sek, Muh. Tahir sek, Mahmud Yunus sek, Harifa Mustafa S.Ei. sek, Fatmawati, dan Sahrun, yang menjadi penyemangat tersendiri bagi saya selama penelitian dan penulisan. Untuk Ibu Suwarni dan mendiang Bapak Sumargo beserta keluarga besar mertua di Semarang yang telah membantu kelanca ran studi saya dari awal, dan senantiasa mendoakan agar proses penelitian dan penulisan ini selesai. Akhirnya, saya harus menyebut istri saya tercinta, Diany Marganingsih S.Sos. MPA, serta putri-putriku tersayang, titipan Allah, yang telah memberi banyak kesempatan selama penelitian dan penulisan ini. Keceriaan dan suasana yang romantis senantiasa memberi motivasi dan doa yang tulus bagi saya.

Semoga karya ini menjadi jawaban yang memadai terhadap segala bantuan, bimbingan, dan pendidikan dari semua pihak yang terlibat. Hanya kepada Allah Swt. saya berserah diri dan memohon balasan yang setimpal kepada mereka semua.

Yogyakarta

Penulis

\section{BAB 1}

\section{PENDAHULUAN}

Buku ini merupakan hasil penelitian yang dilatarbelakangi oleh kerisauan penulis terhadap krisis keindonesiaan pasca reformasi, yang berakibat pada rapuhnya kondisi sosial, ekonomi, dan politik, serta krisis moralitas yang melanda sebagian besar masyarakat Indonesia.

Sikap dan perilaku yang menyimpang bisa dijumpai dalam kehidupan bernegara. Tata hukum dan tata negara disinyalir cenderung berpihak pada kepentingan penguasa. Tampaknya, sistem demokrasi yang ada hanya dinikmati oleh penguasa. Dalam konteks ini, korupsi, kolusi, nepotisme, pelanggaran hukum, dan pelecehan kemanusiaan oleh penguasa didesain dengan sistem dan mekanisme yang samar di mata publik. Padahal, Indonesia diklaim memiliki koridor hukum dan landasan etika (agama) yang jelas. Di sisi lain, Indonesia dikenal sebagai negara dengan penganut agama (Islam) terbesar, sehingga perilaku masyarakatnya dinilai sebagai representasi ajaran agama yang dianutnya Kenyataannya, hukum dan peraturan ternyata tidak men jamin terciptanya perilaku etis dalam kehidupan berbangsa bernegara. Banyaknya aturan tidak mengurangi pelanggaran yang terjadi. Secara tekstual dan normatif, aturan dan perundang undangan serta agama yang memuat ajaran tentang etika, menolak sikap dan 
perilaku tidak etis, sehingga di dalamnya termuat sanksi dan ancaman terhadap sikap dan perilaku tidak etis. Tampaknya realitas kehidupan berbangsa-bernegara tidak menghargai anjuran-anjuran etika yang ada.

Penggunaan terjemahan karya-karya Syaikh Yusuf dala kajian ini lebih sebagai bahan perbandingan, dengan pertimbangan bahwa terjemahan ini merupakan karya yang dapat dipertanggung jawabkan karena dilakukan oleh penulis yang berkompeten di bidang kajian ini.

Kajian pustaka dengan sumber data sekunder tentu saja bermanfaat, sehingga kajian ini bersifat deskriptif-analisis yang mendalam (thick description). 23 Pendekatan yang berbasis pada ontologi, epistemologi, dan aksiologi dalam mengkaji tokoh beserta karya-karyanya, menjadi sangat penting dan merupakan dimensi pokok kajian kefilsafatan.24Penelitian kualitatif pada umumnya berorientasi eksploratif dan logis. Pendekatannya bersifat induktif, yakni peneliti berupayamenyikapi situasi dengan cara rasional. Metode ini menekankan pentingnya pemahaman makna dari perilaku manusia dan konteks sosio-budaya dari suatu interaksi sosial. Metode ini mengembang kan pemahaman empiris antara persepsi personal dan perilakunya. Tahapan metodis dalam kajian ini adalah mengumpulkan sumber-sumber data yang berhubungan dengan objek kajian. Data yang diperoleh diklasifikasi dan dideskripsikan secara padat dan mendalam. Metode ini dipakai sejak persiapan penelitian,

pengumpulan data, dan analisis data. Tahapan selanjutnya adalah analisis data yang dilakukan sejak tahapan pengumpulan data. Karena objek penelitian yang dikaji berkaitan dengan teks, sejarah, keadaan individu dan sosial masyarakat, maka digunakan beberapa metode dan pendekatan, antara lain: metode historis untuk analisis sejarah, dalam hal inimenganalisis sejarah kelahiran dan pendidikan Syaikh Yusuf.

Metode verstehen untuk memahami data berdasarkan karakte ristiknya masing-masing, terutama konsep-konsep karya Syaikh Yusuf. Metode interpretasi untuk menunjukkan arti, serta mengungkapkan pemikiran filosofis secara objektif. Metode hermeneutik untuk menangkap makna sesuai dengan konteksnya, khususnya konsep-konsep etika yang terdapat di dalam karya karya Syaikh Yusuf. Metode analitik bahasa untuk menganalisis konsep pemikiran dalam teks yang sifatnya terminologis. Metode abstraksi untuk melakukan analisis dan menangkap makna sampai pada tingkat hakikat. Terakhir, metode intuitif dan metode heuristik, yaitu untuk menemukan suatu jalan baru yang merupakan suatu pemikiran baru setelah melakukan penyimpulan, kritik atau menemukan suatu metode baru.

\section{BAB 2}


Sejarah Syaikh Yusuf tidak terlepas dari sejarah suku Bugis Makassar Sulawesi Selatan. Di antara sumber-sumber penelitian tentang kehidupan suku Bugis-Makassar adalah pertama, Lontara atau Lontarak, yakni kitab bacaan yang merupakan rekaman masa lalu Sulawesi Selatan. Kedua, La Galigo atau I La Galigo, yaknikarya sastra Bugis yang disebut-sebut sebagai karya sastra terbesar tahun 1860 oleh bangsawan Bugis dari Tanate bernama Collipujie Arung Pancana Toa Datu Tanate. Ketiga, arsip-arsip atau naskah yang ditulis oleh sarjana asing atau sebagai arsip-arsip kolonial yang walaupun masih menimbulkan banyak polemik.3 Istilah Lontara atau dalam bahasa Makassar Lontarak merujuk pada beberapa pengertian, yaitu: abjad atau huruf, cerita, atau bacaan, sejenis pohon dan lain-lain yang semuanya menjadi lambang identitas suku Bugis, Makassar, termasuk Mandar. Sedangkan La Galigo merupakan naskah kuno yang menceritakan keadaan atau sejarah Sulawesi Selatan sebelum masuknya Islam. La Galigo sendiri menurut Soebadio. merupakan peninggalan budaya yang telah diakui mempunyai kepentingan besar sekali guna memahami pikiran yang meskipun berbau mitologi dan berupa masa yang sudah lampau namun konteksnya masih berlaku dan menjadi dasar yang sangat penting untuk memahami sendi sendi perwatakan suku di Sulawesi Selatan.

\section{A. Biografi dan Latar belakang Pemikiran Syaikh Yusuf}

\section{Kelahiran}

Yusuf (nama kecil Syaikh Yusuf) lahir di Makassar pada tahun 1626 M. Lontarak Syaikh Yusuf menceritakan bahwa Yusuf lahir di istana Tallo pada 3 Juli 1626 M/8 Syawal 1036 H, dari puteri Gallarang Moncongloe di bawah pengawasan Raja Gowa. Menurut Da Costa dan Davis, orang tua Syaikh Yusuf termasuk kaum bangsawan. Ibunya memiliki hubungan darah dengan Raja-raja Gowa, sedangkan ayahnya masih kerabat Sultan Alauddin, salah satu penguasa di Sulawesi Selatan pada saat itu. Gelar "syaikh" diperoleh dari seorang mursyid tarekat yang membimbingnya, sesuai dengan tradisi ahli tasawuf.

Dalam Tuhfat al-Mursalah, karya Syaikh Yusuf, tertulis nama al-Syaikh Yusuf al-Taj Abu alHarkani Majalawi. Nama ini menunjukkan seorang waliyullah yang mengetahui asal-usulnya, yaitu keturunan bangsawan Lili negeri Majalawi Makassar. Dalam al-Naba Fi I'rab La ilaaha illallah, tertulis nama al-Syaikh Yusuf bin Abdullah al-Jawi al-Makassari, yang menunjukkan bahwa dia adalah wali sufi dari Tanah Jawi dan Makassar.24 Gelar "syaikh" diperoleh menurut tradisi tasawuf setelah ia mendapat izin dari gurunya di Damaskus yang bernama al-Syaikh Abu al-Barokah Ayyub bin Ahmad bin Ayyub al-Khalawaty al-Quraisy, karena Syaikh Yusuf memiliki kemampuan dan penguasaan dalam tarekat. Bagi kalangan sufi, hanya orang-orang yang telah mencapai tingkat tertentu yang berhak memperoleh gelar itu. Nama lengkapnya dalam bahasa Arab adalah Syaikh al-Haj Yusuf Abu al-Mahasin Hadiyatullah al-Taj al-Khalwati al-Maqashshariy. Nama itu dalam bahasa Indonesia memiliki arti: "Syaikh Haji Yusuf yang mempunyai berbagai macam kebajikan”. Menurut Azumardi Azra, gelar syaikh memiliki makna universal, yang dalam 
sejarah Nusantara berhubungan dengan ulama yang menguasai tasawuf. Syaikh Yusuf adalah tokoh tasawuf dari Makassar yang berpengaruh dan berperan dalam pengembangan dakwah Islam, sehingga namanya disebut juga Syaikh Yusuf Taj al-Khalwaty al Makassary.

\section{Bab III}

\section{BASIS PEMIKIRAN ETIKA RELIGIUS SYAIKH YUSUF}

Pada prinsipnya, karya-karya Syaikh Yusuf menekankan pada pentingnya penguasaan syar'iat, baik secara lahir maupun batin. Hampir semua karyanya yang berhasila ditemukan berkaitan dengan masalah tasawuf dan tarekat, selain masalah keislaman lainnya. Hamid mengidentifikasi karya Syaikh Yusuf berjumlah 29 karya, sedangkan Tudjimah mengidentifikasi 23 karya.

Penulis mendapatkan karya-karya Syaikh Yusuf dalam bahasa Arab, yang pembahasannya berkisar pada masalah tasawuf. Dimensi mistiknya sangat dominan, bahkan dapat dikatakan merupakan master key dari seluruh karyanya. Menurut Cawidu,3 keterlibatan Syaikh Yusuf dalam tarekat dan tasawuf sangat dalam dan total. Hal ini terlihat dari kisah pengembaraan ilmiahnya ke berbagai negara, berguru kepada syaikh-syaikh tarekat dan sufi sufi besar, sehingga hampir semua tarekat besar di dunia Islam telah dijalani.

Konsep etika religius menitikberatkan pada perbuatan dan pengamalan dari ajaran agama. Etika religius Syaikh Yusuf dipandang sangat relevan dengan kondisi di Indonesia pada saat ini, karena pemikirannya mengandung kritik sosial dengan menawarkan hakikat Islam secara lahir dan batin atau mengerti syari'at dan tasawuf, lebih-lebih jika dikaitkan dengan perkembangan dakwah Islam di Indonesia saat ini. Di tengah kegandrungan juru dakwah yang mengadopsi ulama Timur Tengah atau Arab, eksistensi tokoh lokal justru jauh lebih kontekstual dengan karakteristik masyarakat Indonesia.

Untuk memahami landasan etika religius Syaikh Yusuf, kita perlu mengetahui terlebih dahulu beberapa konsep kunci dalam karya-karyanya. Konsep-konsep tersebut merupakan empat tingkatan dalam praktik sufisme, yaitu syari'at, tarekat, hakikat, dan makrifat.

\section{A. Syari'at}

Syari'at adalah jalan terang dan jalan baik yang dapat diikuti oleh setiap orang. Syaikh Yusuf memberikan makna filosofis dalam karyanya, al-Nafhat al-Sailaniyya, bahwa syari'at adalah kata kata atau pemahaman Islam (teaching of Islam.)8 Makna yang paling mendasar, 
syari'at adalah etika dan moralitas yang bisa ditemukan pada semua agama. Syari'at menyediakan tuntutan untuk hidup dengan sebaik-baiknya di dunia ini. Tanpa mengikuti syari'at, ibarat membangun rumah tanpa fondasi. Karena kehidupan dibangun di atas prinsip-prinsip moral dan etika, maka mistisisme tidak dapat berkembang.

\section{B. Tarekat}

Dalam al-Nafhat al-Sailaniyya, Syaikh Yusuf memaknai tarekat sebagai hal atau kondisi diri untuk menghampiri Allah (the way to God). Tarekat mengacu pada praktik atau laku sufisme. Jalan ini tidak selalu terang seperti halnya jalan raya, dan juga bukan jalan yang bisa dilihat dengan kasat mata. Dalam konteks ini, syari'at hanya mengacu pada aspek lahiriah, sedangkan tarekat pada laku batiniah/sufisme. Pemandu yang dibutuhkan adalah seorang syaikh atau guru sufi yang dapat menunjukkan jalan untuk mencapai Tuhan. Syari'at membuat kehidupan seharihari menjadi menarik, sedangkan hakikat dirancang untuk membentuk kehidupan batin menjadi bersih dan murni. Dalam hal ini, syari'at dan hakikat bersifat saling melengkapi.

\section{Hakikat}

Menurut Syaikh Yusuf, hakikat adalah hati, batin atau gnosis (my heart).38 Hakikat mengacu pada makna terdalam dalam praktik dan bimbingan yang dibangun dalam syari'at dan tarekat. Hakikat adalah pengalaman langsung dalam kondisi mistis dalam sufisme dan pengalaman langsung dari kehadiran Tuhan dalam diri. Tanpa pengalaman ini, para murid hanya mengikuti secara buta, berusaha meniru orang yang telah mencapai tingkatan (maqam) hakikat. Pencapaian hakikat memperkuat dan memperkokoh laku pada dua tingkatan, yaitu sebelum sampai pada hakikat, seluruhnya adalah peniruan. Tanpa pemahaman batin yang mendalam dan lahir dari pengalaman, maka orang hanya mengikuti ajaran dan laku orang lain secara mekanistis.

\section{D.Makrifat}

Dalam al-Nafhat al-Sailaniyya, Syaikh Yusuf memaknai kata "makrifat" sebagai rahasia atau hakikat (gnosis). Makrifat adalah kearifan puncak atau pengetahuan tentang kebenaran spiritual. Makrifat adalah level yang paling dalam dan tinggi dari penge tahuan batin dan melampaui hakikat. Makrifat lebih dari sekadar pengalaman spiritual sesaat, dan makrifat merujuk pada kondisi kondisi keselarasan dengan Tuhan dan kebenaran. Makrifat adalah pengetahuan tentang realitas yang dapat dicapai oleh hanya sedikit orang. Makrifat merupakan tingkatan para nabi, rasul, waliyullah, dan para bijak.

\section{Bab IV}




\section{UNIVERSALISME PESAN ETIS}

\section{DALAM KARYA SYAIKH YUSUF}

Etika religius Syaikh Yusuf merupakan etika yang memiliki landasan normatif yang bersumber pada keyakinan dan pengalaman keberagamaan. Etika ini menitikberatkan pada dimensi relasi dan harmonisasi kehidupan manusia dengan Sang Pencipta berdasarkan suatu pandangan universal dan rasional. Hubungan ini sangat signifikan, karena sebagai makhluk yang lemah, manusia selalu resah dan memiliki ketergantungan kepada yang lebih kuat dan perkasa. Ketergantungan ini terkait dengan tindakan dan sikap manusia tentang yang baik dan buruk, serta dengan kebahagiaan hidup di dunia dan di akhirat. Bagi penganut pandangan filsafat etika an sich tanpa agama, yang terpenting adalah melakukan tindakan baik yang secara umum diakui oleh masyarakat: tindakan itu baik dan mendatangkan kebaikan bagi diri sendiri dan orang lain. Sementara itu, dimensi hidup setelah mati tidak berkaitan dengan Tuhan. Kebahagiaan dalam pandangan filsafat etika seperti ini adalah memberi kebahagiaan bagi diri sendiri dan orang lain melalui tindakan yang benar dan etis.

\section{Bab V}

\section{REFLEKSI TEORETIS ETIKA RELIGIUS SYAIKH YUSUF}

Pada dasarnya, setiap ilmu pengetahuan saling berhubungan, baik yang sifatnya berdekatan, pertengahan maupun yang ber jauhan. Ilmu-ilmu yang berhubungan dengan ilmu akhlak atau etika dikategorikan berdekatan dengan ilmu tasawuf, ilmu tauhid, ilmu pendidikan, ilmu jiwa, dan filsafat, sedangkan yang dikategori kan pertengahan adalah ilmu hukum, ilmu sosial, ilmu sejarah, dan ilmu antropologi. Sementara itu, ilmu-ilmu yang jauh hubungannya dengan ilmu akhlak adalah ilmu fisika, biologi, dan ilmu politik. Filsafat etika adalah sebuah upaya untuk men sistematisasikan pengetahuan tentang hakikat moralitas dan apa yang dituntut, seperti yang diucapkan oleh Socrates, bagaimana seharusnya hidup, dan mengapa harus hidup demikian Pandangan tentang hakikat moralitas memiliki kaitan yang erat dengan Islam, sebab satu pesan penting dalam ajaran agama Islam adalah pembentukan moral atau akhlak yang baik, Islam menyebutnya hablum minallah (hubungan dengan Allah) dan hablum minannas (hubungan dengan manusia) .

\section{A. Refleksi dalam Konteks Keindonesiaan}


Terkait dengan krisis kemanusiaan yang terjadi di Indonesiadewasa ini, ada dua teori yang perlu ditempatkan, yaitu: huma nisme dan radikalisme. Kedua teori ini akan diangkat dalam dua kenyataan yaitu humanisme yang diajarkan oleh Syaikh Yusuf yang masih relevan untuk diaktualisasikan, dan radikalisme agama yang digerakkan oleh organisasi-organisasi seperti Front Pembela Islam (FPI) yang muncul di Indonesia.

Humanisme yang dikembangkan oleh kaum sufi seperti Syaikh Yusuf sangat kontras dengan humanisme model Barat, yang tidak memiliki muatan moral dan wawasan spiritual karena ia muncul dari ontologi dan epistemologi yang mengagungkan manusia, yang menjadikan manusia sebagai pusat dan ukurannya. Humanisme Barat, kosong dan semu karena lebih mementingkan peradaban pikir (Iptek) dan materi yang pada akhirnya berujung pada dehumanisasi, demoralisasi, dan despiritualisasi.

\section{B. Rekonstruksi dan Tawaran Metodologis}

Sebelum melangkah ke perdebatan pemikiran etika, pentinguntuk membahas dan memberikan gambaran tentang hakikat ilmu.IImu merupakan kumpulan pengetahuan yang mempunyai ciri ciri tertentu yang membedakan ilmu dengan pengetahuan yanglain. Kajian tentang hakikat keilmuan merupakan kajian filsafatyang biasanya meninjau dari tiga segi penting yaitu, ontologi, epis temologi dan aksiologi ilmu pengetahuan. Filsafat mempelajari masalah ini sedalam-dalamnya dan hasil pengkajiannya merupa kan dasar bagi eksistensi ilmu. Ciri-ciri keilmuan didasarkan pada jawaban yang diberikan ilmu terhadap tiga pertanyaan pokok.Ketiga pertanyaan pokok itu mencakup masalah tentang apa yang ingin diketahui? Bagaimana cara mendapatkan pengetahuan tersebut? Apa nilai kegunaannya?9B. Rekonstruksi dan Tawaran Metodologis Sebelum melangkah ke perdebatan pemikiran etika, pentinguntuk membahas dan memberikan gambaran tentang hakikat ilmu. Ilmu merupakan kumpulan pengetahuan yang mempunyai ciri ciri tertentu yang membedakan ilmu dengan pengetahuan yang lain. Kajian tentang hakikat keilmuan merupakan kajian filsafat yang biasanya meninjau dari tiga segi penting yaitu, ontologi, epis temologi dan aksiologi ilmu pengetahuan. Filsafat mempelajari masalah ini sedalam-dalamnya dan hasil pengkajiannya merupa kan dasar bagi eksistensi ilmu. Ciri-ciri keilmuan didasarkan pada jawaban yang diberikan ilmu terhadap tiga pertanyaan pokok. Ketiga pertanyaan pokok itu mencakup masalah tentang apa yangingin diketahui? Bagaimana cara mendapatkan pengetahuan tersebut? Apa nilai kegunaannya?

Secara keseluruhan, filsafat etika dalam Islam bersumber dari iman, yang merupakan syarat utama untuk mencapai kesempurnaan (insan kamil), yang tergambar jelas dalam konsepsi manusia sebagai khalifah di dunia. Manusia yang memiliki keabsahan menyandang tugas sebagai khalifah adalah manusia yang beriman, yang memandang alam dan seluruh isinya dengan optimistis dan memiliki tujuan-tujuan tertentu. Iman juga menerangi hati manusia dan membimbingnya ke arah kebenaran dan memberikan harapan bagi hasil-hasil dari suatu perbuatan yang baik. 
Pengaruh lain dari iman adalah memberikan kebahagiaan jiwa dan rohani dalam diri manusia. Kebahagiaan semacam ini diperoleh misalnya dari sifat murah hati dan suka menolong. Selain itu, iman juga berfungsi untuk memperbaiki hubungan hubungan sosial seperti saling menghargai hak dan peraturan serta pembatasan-pembatasan yang berlaku serta kepercayaan satu sama lain atas dasar nilai-nilai spiritual. Setiap individu memandang dirinya memiliki tanggung jawab dan kewajiban kepada masyarakatnya, memperlihatkan kebaikan dan ketulusan yang sama, baik dalam kehidupan pribadi maupun dalam kehidupan sosial.

Pada akhirnya, iman memberikan bantuan dan kelapangan pada kesengsaraan dengan membentuk kekuatan dalam dirimanusia untuk mengubah penderitaan menjadi kebahagiaan. Dengan iman pula ilmu pengetahuan digunakan sebagai alat yang bermanfaat bagi kemanusiaan, bukan sebaliknya, yaitu sebagai monster yang membahayakan kehidupan manusia. Keimanan akan menjadi norma tertinggi, etik, atau kerangkaorientasi bagi manusia dalam memberikan makna dan penilaian terhadap lingkungan alam, manusia, dan dirinya sendiri. Hal ini selaras dengan karakter filsafat manusia itu sendiri, yaitu keseimbangan antara pikiran yang baik dan tubuh yang baik.

Dari pikiran yang baik dan tubuh yang baik ini, manusia dapat menyeimbangkan kehidupan dan alam sekitarnya.Jadi, jiwa berpikir secara potensial dan apabila bentuk-bentuk dari pikiran tersebut di atas secara rasional bersatu dalam jiwa, maka jiwa dan akal itu sama, yaitu dalam pengertian telah menyatu dan harmonis dalam pikiran dan dorongan keinginan. Akal akan mengalihkan jiwa menjadi pelaku pemikiran yang aktual. Hal ini sangat penting dalam kaitannya dengan pelaksanaan etika religius dalam kehidupan sehari-hari, karena sebagaimana pandangan filosof Islam, Ibnu Sina, bahwa kekuatan yang pasti adalah kekuatan intelek akal, karena akal yang mendorong pemahamantentang tiga hal penting dalam kepastian filsafat, yaitu metafisika, fisik, dan moral atau kepastian etika. Artinya, akal memiliki peranan yang penting dalam proses filsafat yang tidak hanya berkaitan dengan kehidupan duniawi, tetapi juga ukhrawi. Dalam etika religius, yaitu tanggung jawab dari suatu tindakan tidak hanya berhenti pada tanggung jawabnya di dunia, tetapi juga di akhirat.

Dengan kata lain, etika yang dilakukan di dunia memiliki tanggung jawabnya di dunia dan di akhirat. Oleh karena itu, sufisme yang seringkali menekankan penting nya etika religius dalam segala aspek kehidupan manusia, memiliki kaitan yang erat dengan filsafat. Jika sufisme adalah suatu peng alaman yang digambarkan dalam tindakan untuk menjelaskan kondisi psikologi manusia tentang apa yang dirasakan dalam kaitannya dengan pengalaman ketuhanan, maka pandangan-pandangan filosofis memiliki akar dari kondisi-kondisi psikologis manusia. Pada dasarnya, agama merupakan sesuatu yang misterius, sesuatu yang secara pasti tidak dapat dibuktikannya saat ini. la hanya diyakini dengan keimanan dan bukti-bukti nalar. Inilah sebenarnya inti dari keseluruhan agama, yaitu menyadarkan bahwa ada sesuatu yang tidak dapat dibuktikan secara langsung di dunia ini, karena berkaitan dengan hal-hal yang misterius bagi manusia, yaitu alam metafisika yang hanya dapat dijangkau dengan keimanan atau kepercayaan. 
Etika Religius Syaikh Yusuf dalam Dakwah

Konsep al-takhalluq bi akhlaq Allah (berakhlak dengan akhlak Allah) mengandung arti bahwa seseorang harus berusaha mencontoh dan mempraktikkan sifat-sifat Tuhan (al-asma al husna), kecuali sifat kibr (kesombongan). Melalui jalan ini seseorang akan mencapai kesucian moral lahir dan batin. Hal ini penting dalam melaksanakan dakwah Islam, karena dari basis nilai seperti inilah metode dakwah Syaikh Yusuf diterima dan berkembang. Metode dakwah Syaikh Yusuf sangat adaptif dalam mengembangkan ajaran-ajaran Islam sesuai dengan kondisi objektif Indonesia yang plural, dan hal ini diperkuat oleh penguasaan Syaikh Yusuf terhadap aspek-aspek Islam, baik secara lahir maupun batin. Pemahaman Syaikh Yusuf yang komprehensif ini membuat dakwahnya jauh dari unsur-unsur pemaksaan akandoktrin agama.

Sementara itu, etika sebagai metode merupakan faktor yang terkait dan berpengaruh terhadap keberhasilan dakwah. Pengajaran yang metodis-adaptif oleh Syaikh Yusuf sangat jauh dengan metode dakwah sekarang ini, yang tidak jarang disertai oleh kekerasaan dan teror. Dalam sepak terjangnya, Syaikh Yusuf tidak pernah melakukan provokasi kepada pengikutnya untuk mem benci kelompok lain karena alasan berbeda agama. Corak etika Syaikh Yusuf juga berbeda dengan pola-pola dakwah yang dikembangkan sekarang ini. Etika dakwah Syaikh Yusuf berlangsung secara rasional, estetis, dan etis sehingga mudah diterima oleh masyarakat. Hal ini tidak hanya ditopang oleh keselarasan pandangannya tentang manusia sebagai hamba Tuhan, tetapi juga karena adanya kesejajaran intensitas amal dan perilakunya secara lahir dan batin, atau sebagai corak dasar

dakwah yang sufistik. Oleh karena itu, metode dan substansi dakwah Syaikh Yusuf perlu diapresiasi dalam konteks Indonesia sekarang ini, karena coraknya yang mengayomi, menyejukkan, dan mencerahkan serta jauh dari tindakan anarkis dan teror, sehingga Islam sebagai rahmatan lil alamin dapat diwujudkan. Ajaran pokok etika Syaikh Yusuf dalam dakwahnya, sebagai mana dikemukakan dalam Zubdatul Asrar, adalah tentang akhlak yang baik kepada semua makhluk Tuhan.

Yusuf mengatakan:

Wa yajiu alihi aydlan tahsinul khuluqi ma'al khalaiq kulluhum liannahu sallallahu alaihi wasallam qad suila 'an ayyinnasi, aqrabu ilaika yaumal qiyamah yaa Rasulallah fa ajaba anhu sallallahu alaihi wasallam innama buitstu liutammima makaarimal akhlak. Falihadza qala ba'du ahli suluki radiallahu anhu, at tasawwuf huwa husnul khulqi faman laysa lahu husnul khuluqi, laa tasawwafa lahu, fafham dzalika, tsumma tadammana jumlata husnil khuluyqi aydan fi qaulihi 
sallallahu alahi wasallam, akrim al duyuf walau kana kafiran.

Terjemahannya adalah:

Dan hal yang terpenting juga adalah etika atau akhlak yang baik.

Karena Rasulullah Saw. pernah ditanya, "siapakah orang yang palingdekat denganmu pada hari kiamat hai Rasulullah?" Maka dijawab oleh Rasulullah Saw., "bahwa sesungguhnya aku diutus untuk menyempurnakan akhlak yang mulia. Oleh karena itulah berkata sebagian ahli tasawuf: "Tasawuf adalah akhlak yang mulia, barangsiapa yang tidak berakhlak mulia maka ia tidak bertasawuf. Pahamilah itu."Akhlak yang mulia itu tercakup dalam sabda Rasul sebagai berikut:

"Tempatkanlah manusia sesuai dengan derajatnya masing-masing".

Dan sabdanya: "Muliakanlah tamu meskipun ia adalah orang kafir."

(Dalam Lubis, 1996: 88-89).

Dakwah Syaikh Yusuf secara prinsipil berdasar pada etika, bahwa perbuatan yang baik dengan moral yang baik terhadap sesama merupakan dakwah utama yang dianjurkan oleh Islam. Dengan dakwah melalui etika dan perilaku yang baik, ketentraman masyarakat yang majemuk dapat terjaga, sebagaimana telah ditunjukkan dalam sejarah awal Islam di Indonesia. Meskipun dalam perkembangannya muncul kekerasan, hal itu tidaklah layak disebut sebagai proses dakwah, tetapi merupakan kesempitan berpikir dari sebagian kaum muslim.

Dalam kaitannya dengan etika Islam pada periode Islam awal di Makah dan Madinah, etika Islam yang diterapkan Nabi menjadi begitu penting, sebagai suatu aturan dalam berperilaku karena hal itu sangat dibutuhkan bagi masyarakat individualistik yang pada saat itu secara populasi sedang berkembang. 27

Dalam perjalanan sejarah Islam di Nusantara, khususnya di Sulawesi Selatan, hubungan yang baik antara Sulawesi Selatan dan Aceh merupakan aspek sejarah Islam Nusantara yang positif dan relevan bagi pengembangan dakwah selanjutnya. Menurut Mattulada, kerajaan di Sulawesi yang mula-mula menerima Islam adalah Kerajaan Gowa-Tallo sekitar tahun $1014 \mathrm{H}$ (1605). Sementara itu, menurut Thomas Arnold, ketika Portugis pertama kali memasuki Sulawesi Selatan pada tahun 1540 M, telah ditemukan beberapa orang Islam di Gowa, ibukota Kerajaan Makassar dan baru pada awal abad XVII, Islam dianut oleh sebagian besar rakyat. 
Pada dasarnya, setiap ilmu pengetahuan saling berhubungan, baik yang sifatnya berdekatan, pertengahan maupun yang ber jauhan. Ilmu-ilmu yang berhubungan dengan ilmu akhlak atau etika dikategorikan berdekatan dengan ilmu tasawuf, ilmu tauhid, ilmu pendidikan, ilmu jiwa, dan filsafat, sedangkan yang dikategori kan pertengahan adalah ilmu hukum, ilmu sosial, ilmu sejarah, dan ilmu antropologi. Sementara itu, ilmu-ilmu yang jauh hubungannya dengan ilmu akhlak adalah ilmu fisika, biologi, dan ilmu politik. Filsafat etika adalah sebuah upaya untuk men sistematisasikan pengetahuan tentang hakikat moralitas dan apa yang dituntut, seperti yang diucapkan oleh Socrates, bagaimana seharusnya hidup, dan mengapa harus hidup demikian1.

Pandangan tentang hakikat moralitas memiliki kaitan yang erat dengan Islam, sebab satu pesan penting dalam ajaran agama Islam adalah pembentukan moral atau akhlak yang baik, Islam menyebutnya hablum minallah (hubungan dengan Allah) dan hablum minannas (hubungan dengan manusia).Di samping itu, pandangan etika Syaikh Yusuf termasuk dalam kategori etika religius karena pandangan-pandangan tersebut memiliki landasan pada ajaran agama Islam yang menekankan pada harmonisasi kehidupan dunia dan akhirat. Artinya ajaran ajaran Islam mengajarkan bahwa etika yang dilakukan dalam tindakan hidup sehari-hari mempunyai konsekuensi dan tanggung jawab tidak hanya kepada sesama manusia, tetapi juga kepada Tuhan.

Inti dakwah Syaikh Yusuf, adalah kebaikan moral dan etika luhur pada sesama manusia, bahkan pada sesama makhluk Tuhan. Dalam hal ini ajaran-ajaran etikanya yang berlandaskan ajaran Islam mengandung pesan-pesan moral dan spiritual yang dapat digali serta dikembangkan, terkait dengan filsafat dakwah bagi masyarakat Indonesia yang majemuk. Hal ini penting untuk ditekankan, karena sebagai putra daerah, atau ulama yang lahir di bumi Nusantara, Syaikh Yusuf telah membuktikan bahwa selain memahami ajaran-ajaran Islam dengan baik secara lahiriah atau fiqh dan secara batin, Syaikh Yusuf juga memahami sejarah dan kebudayaan bangsanya. Ragam pengetahuan tersebut membuat dakwah Syaikh Yusuf berhasil,disamping itu ia dapat membanding kan dan mempertimbangkan kondisi-kondisi psikologis serta sosial budaya dan pandangan filsafat masyarakat berdasarkan kebudaya annya. sebagaimana Ibnu Arabi, dari syari'at sampai hakikat di dalam ajaran Syaikh Yusuf, merupakan pokok keberhasilan mengatasi problematika kehidupan. Manusia menjadi sadar bahwa kekuatan dan kemauan untuk mengamalkan agama termasuk untuk mengembangkan dakwah agama, harus dibarengi dengan "bayang bayang" kehadiran Sang Penentu dan Penilai benar dan salahnya, atau baik dan buruknya cara beragama. Mengakui adanya Dia, berarti semua yang dimiliki relatif dan bukan standar utama atas kebenaran maupun kebaikan. Kebenaran dan kebaikan mutlak serta pengklaimannya hanya milik Dia, hanya Dialah yang bisa sombong, angkuh, arogan, berkuasa, dan menguasai. Walaupun sifatsifat itu amat mungkin Dia tunjukkan, tetapi kenyataannya, jarang dilakukanNya, mengapa sebagian atau mungkin seluruh manusia merasa bisa benar dan baik segala-galanya? Seorang ulama yang sudah lama meninggalkan dunia dan memberikan konsep sebagai koreksi atas 
kekeliruan dalam beragama, bisa jadi tidak tenang bahkan marah di alam sana, melihat tingkah manusia yang berani menduduki kursi-kursi kekuasaan yang tidak pernah sedikitpun ditinggalkan oleh Yang Maha Kuasa. Humanisme Islam adalah kemanusiaan yang bermoral, beretika, dan etika huma nisme,90 sebagaimana yang diajarkan oleh Syaikh Yusuf ditampil kannya dalam tiga wilayah sekaligus, yakni ulama, birokrat, dan sufi.

Syaikh Yusuf dikenal sebagai figur dai, ahli tarekat, sekaligus ulama syari'at yang andal. Sebagai sufi besar, ia menguasai dan mengamalkan ajaran Islam secara menyeluruh dan telah mencapai puncak pendakian spiritual tertinggi dalam suluknya, sehingga menjadi wali yang suci dan karomah, bahkan ia berperan juga dalam persoalan sosial dan politik. la menjadi tokoh ulama di Kerajaan Islam Makassar, mufti di Kerajaan Islam Banten, juga pejuang yang memiliki patriotisme besar melawan kedzaliman penjajah di Nusantara, bahkan menjadi tokoh yang berpengaruh di berbagai negara. Syaikh Yusuf adalah salah satu mujadid terpenting dalam sejarah Islam di Indonesia. Jejaknya meliputi wilayah yang sangat luas, dari Sulawesi Selatan dan Jawa Barat,sampai ke Arabia, Sri Lanka, dan Afrika Selatan.

Dimensi sufistik ajaran-ajaran Syaikh Yusuf sangat dominan. Keterlibatan Syaikh Yusuf dalam dakwah dan tarekat sangat ekstensif. Hal ini terlihat pada pengembaraan pengetahuan dan spiritualnya ke berbagai daerah sejak di Makassar hingga ke beberapa negara. Pandangan filsafat Syaikh Yusuf merupakan paduan dari dari para filosof Yunani kuno yang diinterpretasi oleh tokoh-tokoh pemikir Islam sebelum Syaikh Yusuf, yang kemudian mengalami perbedaan corak. Pemikiran Syaikh Yusuf dipengaruhi oleh tokoh-tokoh berpengaruh seperti Ibrahim bin Adham, Imam al-Ghazali, Ibnu 'Ataillah al-Iskandari, Abdul Qadir Jailani, Abdul Karim al Jilli, dan Rabiah al-Adawiyah serta dua tokoh lain yang jarang disebut dalam karya-karyanya, yaitu Ibn Arabi dan Ibn Miskawih. Teori-teori etika religius yang dikembangkan Syaikh Yusuf bersumber dari Al-Qur'an, tentang manusia dan kedudukannya di alam semesta. Etikanya didasari pada pandangan dunia Al-Qur'an, sunnah, konsep-konsep teologi, kategori-kategori filsafat, dan sufisme. Unsur utama pemikiran etika ini berpusat pada dunia dan manusia. Sistem etika ini muncul dalam bentuk yang kompleks, yaitu teosentris, antroposentris, dan kosmosentris.

Bangunan konsep Syaikh Yusuf merupakan perpaduan antara unsur akal (rasio), rasa (estetis), dan kehendak (etika yang berbasis ilahiah). Konsepsi Syaikh Yusuf tentang Tuhan (teologi) bercorak sintesis antara paham ta'thil (pengosongan Tuhan dari sifat-sifat) dan paham tasybih. Mengenai alam semesta (kosmologi), tampak nya Syaikh Yusuf terpengaruh oleh para pemikir sebelumnya.

Hakikat alam adalah tidak ada. Yang ada hanya Tuhan yang menciptakan. Karena itu, semua yang diciptakan oleh Yang Ada hanya penampakan lahir (tajali) dari Tuhan. Sementara tentang manusia (antropologi), Syaikh Yusuf mengatakan bahwa hakikat manusia adalah bayangan Tuhan di muka bumi. Namun demikian, antara Tuhan dan hamba harus tetap ada 
perbedaan. Hamba tetap hamba betapa pun ia telah sampai ke puncak kesatuan dengan

Tuhan, dan Tuhan tetap Tuhan meskipun Dia turun kepada hamba Nya. Manusia yang seperti ini disebut sebagai insan kamil. Konsep etika Syaikh Yusuf pada hakikatnya berdasarkan prinsip al-takhalluq bi akhlaq Allah (berakhlak dengan akhlak Al lah). Moralitas hidup harus seiring dengan sikap dan perilaku yang beradab. Keberadaban ini tidak hanya sekadar rasa solidaritas sosial, tetapi juga merupakan solidaritas yang didasarkan pada unsur-unsur primordial. Relasi etika Syaikh Yusuf dan dakwah Islam berhubungan dengan tiga hal, yaitu: manusia, pribadi, dan makhluk Tuhan. Etika religius Syaikh Yusuf merupakan pandangan moralitas religius yang universal, mencakup kebutuhan materiil dan spirituil. Secara materiil, ia menjadi landasan etos kerja dan aktivitas serta menjadi pendorong berkarya sebagai bentuk tanggung jawab sosial kepada sesama manusia. Secara spirituil, ia melandasi segala aktivitas kehidupannya dalam bingkai etika religius dan menyadari bahwa tanggung jawabnya tidak hanya kepada manusia dan berhenti di dunia saja, namun juga kepada penciptanya.

Berbeda dengan tawaran-tawaran konsep etika sekuler, etika religius Syaikh Yusuf sebagaimana pandangan Sooren Kierkegaard dan Toshishiko Isutzu, dilandasi oleh ajaranajaran moral agama yang memiliki tujuan ganda, yaitu tujuan untuk kehidupan riil saat ini dan kehidupan yang dijanjikan Tuhan di masa mendatang.

Untuk menjadi hamba Tuhan yang saleh, manusia perlu menjadi saleh secara sosial, sehingga kesalehannya dapat memberikan hasil kepada masyarakat dalam kehidupan seharihari. Konsep insan kamil Syaikh Yusuf terfokus pada esensi kesucian, yakni spiritual manusia yang akan mengantarkan manusia ke alam ilahiah (alam ketuhanan), melalui potensi batinyang dimilikinya sebagai indikasi kesempurnaan spritualnya.

Konsep-konsep seperti ini adalah sesuatu yang batin (dalam), bahwa perkembangan dimensi batin manusia harus diupayakan melalui perjalanan rohani yang sangat berat (mujahadat) dan latihan spiritual yang terus-menerus (riyadah), karena dimensi batin manusia merupakan hakikat dirinya. Idealisasi kesempurna an manusia merujuk pada diri Nabi Muhammad Saw. dari sisi kesempurnaan jiwanya dalam merefleksikan sifat-sifat ketuhanan. Dengan mencontoh perilaku Nabi, manusia dimungkinkan dapat memanifestasikan pola relasinya dengan Tuhan dan dengan etika kebudayaan yang sempurna. Dalam rangka pendakian menuju ke maqam insan kamil, manusia harus merujuk pada syari'at, tarekat, hakikat, dan makrifat. Tingkatan-tingkatan tersebut terintegrasi ke dalam suatu sistem ajaran keberagamaan sehingga meniscayakan manusia menuju tujuan final, yakni jiwa yang siap menerima Tuhan, dan manusia pun mampu mengenal Tuhannya secara sempurna. 
Di dalam konteks gerakan, ajaran-ajaran Syaikh Yusuf dapat menggerakkan suatu aktivitas sehingga berhasil membawa Islam sebagai agama yang maju dan berkembang di dalam masyarakat yang majemuk. Melekatnya dakwah Islam dengan tradisi, strata dan latar belakang masyarakat pada masa Syaikh Yusuf, adalah hal penting untuk diperhatikan, dan karenanya harus menjadi perhatian para juru dakwah sekarang ini, baik secara perorangan maupun institusi. Dalam berbagai literatur, dijelaskan bahwa perbedaan status sosial (ekonomi, pendidikan, lingkungan tempat tinggal) menjadikan intensitas dan derajat pemahaman keagamaan seseorang menjadi berbeda atau beragam. Bahkan latar belakang pendidikan yang tidak sama, perlakuan pendidikan dan faktor status juru dakwah, menyangkut kapasitas dan kapabilitas, kualitas dan profesionalitas, baik itu secara personal maupun institusional, ikut mempengaruhi kesadaran dan partisipasi keberagamaan masyarakat.

Konsep dakwah adalah suatu konsep penyelarasan antara etika dan dimensi estetika sekaligus, memiliki sandaran vertikal sekaligus sandaran horizontal. Corak dakwah Syaikh Yusuf yang tidak hitam-putih, langsung menyentuh aspek syari'at yang paling dalam (batin manusia), dan kemudian melaksanakan ajaran-ajaran syari'at dengan etika lahir-batin yang sangat dibutuhkan. Dengan pendekatan sufistik, Syaikh Yusuf mendapat simpati dari pelbagai lapisan masyarakat, raja, punggawa, dan rakyat jelata.

Keberhasilan ini tidak hanya terjadi di Nusantara, namun juga di mancanegara, tempat Syaikh Yusuf pernah menyebarkan ajaran dan dakwahnya. Dalam sejarah perjalanan dakwah Islam di Nusantara, keberhasilan juru dakwah Islam masa-masa awal dan selanjutnya bertitik tolak dari penerapan etika religius serta pandangan filsafat hidup masyarakat setempat. Mereka telah menunjukkan keber hasilannya di dalam proses dakwah Islam dari masa ke masa. Dalam berdakwah, Syaikh Yusuf telah menunjukkan metode dakwah yang sesuai dengan konteks lokal, sedangkan contoh yang digunakannya tidak terlepas dari etika religius. Selain itu, dalam prosesnya, Syaikh Yusuf juga menunjukkan kapasitas dirinya sebagai seorang ulama sekaligus intelektual yang memiliki pengalaman dan pandangan luas akan dunia keilmuan Islam. Hal ini dapat dilihat dari pengalaman belajar serta rujukan-rujukan yang digunakannya ketika menjelaskan ajaran Islam di dalam karya-karyanya.

Dalam konteks dakwah Islam di Indonesia, kajian tentang etika religius Syaikh Yusuf dapat menjadi acuan yang perlu dikembangkan guna merumuskan ulang paradigma-paradigma filsafat dakwah yang lebih baik, misalnya dakwah etis dalam kaitannya dengan masyarakat nonIslam. Jika mengingat dunia global dan interaksi masyarakat yang makin intensif dalam memenuhi kebutuhan hidup, tentunya masyarakat membutuhkan pandangan dan sikap yang lebih bersahabat, memberi kenyamanan dan ketenangan. Karena itu, etika religius penting dipraktikkan di dalam kehidupan sehari-hari, terutama dalam proses dakwah Islam. 
Etika religius Islam yang dikembangkan oleh Syaikh Yusuf merupakan ajaran-ajaran luhur ketuhanan yang sesuai dengan pandangan-pandangan universal pemikir-pemikir non-muslim lainnya yang juga menaruh perhatian besar pada etika religius. Persamaan dari seluruh pemikir etika religius walaupun berbeda agama adalah bahwa etika hidup yang dikembangkan dalam masyarakat memiliki tanggung jawab kepada sesama individu dalam masyarakat sekaligus tanggung tawab kepada Tuhan. Hal ini jelas berbeda dengan pandangan filsafat yang hanya menekan kan etika dalam kaitannya dengan tanggung jawab di kehidupan dunia saja, tanpa membicarakan tanggung jawabnya di akhirat. Penekanan dalam etika religius adalah pada pandangan dunia yang komprehensif, yaitu dunia kini yang ditempati dan dunia yang akan datang. Pemahaman komprehensif inilah yang sebenarnya dirindukan oleh masyarakat modern yang tampaknya mulai haus akan unsur-unsur spiritual.

\section{Bab VI}

\section{PENUTUP}

Syaikh Yusuf dikenal sebagai figur dai, ahli tarekat, sekaligus ulama syari'at yang andal. Sebagai sufi besar, ia menguasai dan mengamalkan ajaran Islam secara menyeluruh dan telah mencapai puncak pendakian spiritual tertinggi dalam suluknya, sehingga menjadi wali yang suci dan karomah, bahkan ia berperan juga dalam persoalan sosial dan politik. la menjadi tokoh ulama di Kerajaan Islam Makassar, mufti di Kerajaan Islam Banten, juga pejuang yang memiliki patriotisme besar melawan kedzaliman penjajah di Nusantara, bahkan menjadi tokoh yang berpengaruh di berbagai negara. Syaikh Yusuf adalah salah satu mujadid terpenting dalam sejarah Islam di Indonesia. Jejaknya meliputi wilayah yang sangat luas, dari Sulawesi Selatan dan Jawa Barat, sampai ke Arabia, Sri Lanka, dan Afrika Selatan.

Dimensi sufistik ajaran-ajaran Syaikh Yusuf sangat dominan. Keterlibatan Syaikh Yusuf dalam dakwah dan tarekat sangat ekstensif. Hal ini terlihat pada pengembaraan pengetahuan dan spiritualnya ke berbagai daerah sejak di Makassar hingga ke beberapa negara.

Pandangan filsafat Syaikh Yusuf merupakan paduan dari dari para filosof Yunani kuno yang diinterpretasi oleh tokoh-tokoh pemikir Islam sebelum Syaikh Yusuf, yang kemudian mengalami perbedaan corak. Pemikiran Syaikh Yusuf dipengaruhi oleh tokoh-tokoh berpengaruh seperti Ibrahim bin Adham, Imam al-Ghazali, Ibnu 'Ataillah al-Iskandari, Abdul Qadir Jailani, Abdul Karim al Jilli, dan Rabiah al-Adawiyah serta dua tokoh lain yang jarang disebut dalam karya-karyanya, yaitu Ibn Arabi dan Ibn Miskawih.

Teori-teori etika religius yang dikembangkan Syaikh Yusuf bersumber dari Al-Qur'an, tentang manusia dan kedudukannya di alam semesta. Etikanya didasari pada pandangan dunia Al-Qur'an, sunnah, konsep-konsep teologi, kategori-kategori filsafat, dan sufisme. Unsur utama 
pemikiran etika ini berpusat pada dunia dan manusia. Sistem etika ini muncul dalam bentuk yan kompleks, yaitu teosentris, antroposentris, dan kosmosentris Bangunan konsep Syaikh Yusuf merupakan perpaduan antar unsur akal (rasio), rasa (estetis), dan kehendak (etika yan berbasis ilahiah).

Konsepsi Syaikh Yusuf tentang Tuhan (teologi) bercorak sintesis antara paham ta'thil (pengosongan Tuhan dari sifat-sifat) dan paham tasybih. Mengenai alam semesta (kosmologi), tampak nya Syaikh Yusuf terpengaruh oleh para pemikir sebelumnya. Hakikat alam adalah tidak ada. Yang ada hanya Tuhan yang menciptakan. Karena itu, semua yang diciptakan oleh Yang Ada hanya penampakan lahir (tajali) dari Tuhan. Sementara tentang manusia (antropologi), Syaikh Yusuf mengatakan bahwa hakikat manusia adalah bayangan Tuhan di muka bumi. Namun demikian, antara Tuhan dan hamba harus tetap ada perbedaan. Hamba tetap hamba betapa pun ia telah sampai ke puncak kesatuan dengan Tuhan, dan Tuhan tetap Tuhan meskipun Dia turun kepada hamba Nya. Manusia yang seperti ini disebut sebagai insan kamil.

\section{DAFTAR PUSTAKA}

https://books.google.com/books/about/Agama_dan_Bayang_Bayang_Etis_Syaikh_Yusu. html?id=mhReDwAAQBAJ

APA : Mustafa, M. (2011). Agama dan bayang-bayang etis Syaikh Yusuf al-Makassari. LKIS PELANGI AKSARA.

MLA : Mustafa, Mustari. Agama dan bayang-bayang etis Syaikh Yusuf al-Makassari. LKIS

PELANGI AKSARA, 2011.

CHICAGO : Mustafa, Mustari. Agama dan bayang-bayang etis Syaikh Yusuf al-Makassari. LKIS PELANGI AKSARA, 2011.

HARVARD : Mustafa, M., 2011. Agama dan bayang-bayang etis Syaikh Yusuf al-Makassari. LKIS PELANGI AKSARA.

VANCOUVER: Mustafa M. Agama dan bayang-bayang etis Syaikh Yusuf al-Makassari. LKIS PELANGI AKSARA; 2011.

Abdullah, Irwan. 2006. Konstruksi dan Reproduksi Kebudayaan. Yogyakarta: Pustaka 
Pelajar.

Abdullah, M. Amin. 2006. Islamic Studies di Perguruan Tinggi, Pendekatan IntegratifInterkonektif. Yogyakarta: Pustaka Pelajar.

2004. Studi Agama, Normativitas atau Historisitas? Yogyakarta: Pustaka Pelajar.

Abdullah, M. Yatimin. 2006 Studi Etika. Jakarta: PT. Raja Grafindo Persada.

Abduh, Muhammad. 2006. Madza Ya'ni Intimaa'i lid Dakwah. Terj. Ulil Bahruddin. Jakarta: Robbani Press.

Abineno, J.L.Ch. 1994. Sooren Kierkegaard, Filsuf, Religius, danTeolog. Jakarta: BPK Gunung Mulia.

Abu Riddah, M. Abdu al Hadi. 1997. “Razail al Kindi al Falsafiyyah,

Dar al-Fikr al Arabi”. Dalam Nurcholis Madjid, Khazanah

Intelektual Islam. Bandung: Bulan Bintang. Ahmad, Mustaq. 2006. Business Ethics in Islam. Jakarta: Pustaka al-Kautsar.

Ahmad, Muhammad. 1982. "Hubungan Gowa dengan Aceh dalamProses Islamisasi Kerajaan Bugis-Makassar”. Dalam Andi 173. 